\title{
Studi Laju Infiltrasi Pada Lahan Irigasi Gumbasa (Studi Kasus di BGKn 38. 42 dan 51)
}

\author{
B. Afrianto ${ }^{a}$ I.W. Sutapa ${ }^{a}$, N. Hidayat ${ }^{a}$ dan R. Herman ${ }^{a}$ \\ ${ }^{a}$ Jurusan Teknik Sipil, Fakultas Teknik Universitas Tadulako, Jalan Soekarno Hatta Km. 9, Palu, Sulawesi Tengah, Indonesia \\ ${ }^{*}$ Corresponding author's e-mail: wsutapa@yahoo.com
}

Received: 26 August 2021; revised: 19 December 2021; accepted: 17 January 2022

\begin{abstract}
The 2018 earthquake that shook the city of Palu and surrounding areas with the power of 7.4 MW triggered liquefaction in several locations. Earthquakes and liquefaction that occurred caused damage to Gumbasa's irrigation canals and some paddy fields. This study was conducted at three points in the paddy fields which 2 points located in the Soulowe village and Sidera village, District of Dolo and one is located in the Lolu village, District of Biromaru. This study aims to determine the infiltration rate in the residents's paddy fields which have not been planted with paddy for a long time. This is because until the data retrieval performed, Gumbasa irrigation network has not functioned and still under repair. Data were collected using a Double Ring Infiltrometer measuring instrument. The results obtained from this study for constant infiltration rate of BGKn $38=1.27 \mathrm{~cm} /$ hour, BGKn $42=1.10 \mathrm{~cm} /$ hour and BGKn $51=0.75 \mathrm{~cm} /$ hour, which all three are classified as a rather slow with a constant infiltration rate ranging from 0.5 to $2 \mathrm{~cm} /$ hour. For the difference in fc values, BGKn 38 and BGKn 42 at $0.17 \mathrm{~cm} /$ hour and BGKn 42 and BGKn 51 at $0.35 \mathrm{~cm} /$ hour, so that BGKn 38 and BGKn 51 is $0.52 \mathrm{~cm} / \mathrm{hour}$. Meanwhile, the value of the difference f0 from the three points is BGKn 38 with BGKn 42 at $3.82 \mathrm{~cm} /$ hour and BGKn 42 with BGKn 51 at 4.43 $\mathrm{cm} /$ hour, and BGKn 38 with BGKn 51 is $0.61 \mathrm{~cm} /$ hour.
\end{abstract}

Keywords: double ring infiltrometer, initial infiltration rate, constant infiltration rate, classification

\begin{abstract}
Abstrak: Gempa bumi 28 September 2018 yang mengguncang Kota Palu dan sekitarnya dengan kekuatan 7,4 MW memicu terjadinya likuifaksi di beberapa lokasi. Gempa bumi dan likuifaksi yang terjadi ini mengakibatkan rusaknya saluran irigasi Gumbasa dan beberapa lahan persawahan. Penelitian ini dilaksanakan pada 3 titik di lahan persawahan warga yang mana 2 titik terletak di Desa Soulowe dan Desa Sidera, Kecamatan Dolo dan 1 lagi terletak di Desa Lolu, Kecamatan Biromaru. Penelitian ini bertujuan untuk mengetahui laju infiltrasi di lahan persawahan warga yang sudah lama tidak ditanami tanaman padi. Hal ini disebabkan karena sampai saat pengambilan data dilakukan jaringan irigasi Gumbasa belum difungsikan dan masih dalam tahap perbaikan. Pengambilan data dilakukan dengan alat ukur Double Ring Infiltrometer. Hasil yang diperoleh dari penelitian ini untuk laju infiltrasi konstan BGKn $38=1,27 \mathrm{~cm} / \mathrm{jam}, \mathrm{BGKn} 42=1,10 \mathrm{~cm} / \mathrm{jam}$ dan BGKn $51=0,75 \mathrm{~cm} / \mathrm{jam}$, yang mana ketiganya tergolong pada klasifikasi agak lambat dengan laju infiltrasi konstan berkisar antara 0,5 sampai $2 \mathrm{~cm} / \mathrm{jam}$. Nilai perbedaan fe nya, BGKn 38 dengan BGKn 42 senilai 0,17 cm/jam dan BGKn 42 dengan BGKn 51 senilai 0,35 $\mathrm{cm} / \mathrm{jam}$, dan BGKn 38 dengan BGKn 51 senilai 0,52 cm/jam. Sedangkan untuk nilai perbedaan f0 dari ketiga titik yaitu BGKn 38 dengan BGKn 42 senilai 3,82 cm/jam dan BGKn 42 dengan BGKn 51 senilai 4,43 cm/jam, serta BGKn 38 dengan BGKn 51 senilai 0,61 cm/jam.
\end{abstract}

Kata kunci : Double Ring Infiltrometer, laju infiltrasi awal, laju infiltrasi konstan, klasifikasi

\section{Pendahuluan}

Pertanian adalah kegiatan pemanfaatan sumberdaya hayati yang dilakukan manusia untuk menghasilkan bahan pangan, bahan baku industri atau sumber energi, serta untuk mengelola lingkungan hidup [1]. Kegiatan pertanian melibatkan lahan atau permukaan bumi sebagai tempat pengelolaannya. Namun saat terjadinya bencana alam, hal ini dapat merubah tata guna lahan tersebut. Contoh yang paling dekat dengan lahan pertanian adalah kejadian likuifaksi.

Likuifaksi merupakan salah satu bencana geologi yang dapat terjadi ketika guncangan (gempa bumi) sedang berlangsung pada suatu daerah yang tersusun dari litologi pasir yang telah jenuh terhadap air [2]. Hasil penelitian Tohari dkk. (2011) menunjukkan bahwa fenomena likuifaksi terjadi karena keberadaan lapisan berpasir gembur dengan air tanah yang relatif dangkal. Peristiwa ini dapat merusak tata guna lahan yang sebelumnya telah dibuat di atasnya [3].
Bencana alam berupa likuifaksi yang terjadi pada tanggal 28 September 2018 di Sulawesi Tengah telah merubah topografi di beberapa lokasi seperti di Kota Palu (kelurahan Balaroa dan Petobo), sedangkan di Kabupaten Sigi (di Desa Lolu, Jono Oge dan Sibalaya). Dampak dari likuifaksi tersebut salah satunya pada daerah Kabupaten Sigi telah membuat saluran irigasi menjadi rusak dan kegiatan persawahan pun menjadi terhambat akibat tidak adanya pasokan air yang cukup.

Menanggapi hal tersebut Kementerian PUPR dan Kementerian Pertanian bersinergi untuk merehabilitasi jaringan irigasi dan daerah persawahan agar dapat ditanami tanaman padi lagi. Rentang waktu yang cukup lama dan tidak digunakannya lahan persawahan seperti dulu membuat penulis memilih lokasi lahan sebagai tinjauan untuk melakukan penelitian mengenai laju penyerapan air pada tanah di daerah tersebut. Tujuan dari penelitian ini adalah untuk mengetahui berapa besar nilai infiltrasi dan perbedaan laju dari tiap titik pengukuran. 


\subsection{Likuifaksi}

Likuifaksi adalah bencana alam berupa deformasi permukaan tanah akibat tidak mampu lagi mempertahankan bentuk saat terjadi guncangan tiba-tiba. Likuifaksi terjadi pada tanah yang berpasir lepas (tidak padat) dan jenuh air dengan air tanah yang relatif dangkal [3]. Lapisan tanah yang mayoritasnya terdiri dari pasir akan sangat mudah mengalami likuifaksi karena memiliki porositas yang tinggi. Sehingga jika lapisan di bawahnya tidak mudah mengalirkan air dan lapisan pasir sudah jenuh, guncangan berupa gempa akan sangat mudah menjadikan likuifakasi terjadi.

Guncangan gempa menjadikan tekanan air naik dan tegangan efektif tanah berkurang. Akibatnya modulus pasir berkurang sejalan dengan turunnya tegangan efektif dan tanah pasir menjadi melunak atau mencair. Saat situasi ini tanah tidak mampu lagi mempertahankan daya topang pada beban di atasnya sehingga terjadi deformasi seperti longsor atau likuifaksi.

Kurniawan (2020) menyatakan ada 3 faktor utama penyebab likuifaksi yaitu tanah berbutir kasar, posisi muka air tanah yang tidak jauh dari permukaan, dan gempa bumi [4].

\subsection{Siklus Hidrologi}

Siklus hidrologi merupakan perjalanan air dari permukaan laut ke atmosfer kemudian ke permukaan tanah dan kembali ke laut yang terjadi secara terus menerus. Air akan tertahan sementara di sungai, danau/waduk, dan dalam tanah sehingga dapat dimanfaatkan oleh manusia dan makhluk hidup lainnya. Dalam daur hidrologi, masukan berupa curah hujan akan didistribusikan melalui beberapa cara yaitu air lolos, aliran batang, dan air hujan yang langsung sampai ke permukaan tanah untuk kemudian terbagi menjadi air larian, evaporasi, dan air infiltrasi [5].

Informasi tentang sifat-sifat hidrologi tanah dalam hubungannya dengan jenis penggunaan lahan yang berbeda pada umumnya cukup terbatas. Berubahnya kapasitas infiltrasi akan berpengaruh secara langsung terhadap aliran permukaan dan siklus hidrologi pada suatu DAS [6]. Dari siklus hidrologi ini, air hujan yang jatuh di permukaan tanah sebagian akan meresap ke dalam tanah menjadi air tanah, dan sebagian akan mengisi cekungan permukaan dan sisanya merupakan overland flow. Hal ini tergantung dari besar kecilnya intensitas curah hujan terhadap infiltrasi.

Infiltrasi, sebagai salah satu fase dari sirklus hidrologi, penting untuk diketahui karena akan berpengaruh terhadap limpasan permukaan, banjir, erosi, ketersediaan air untuk tanaman, air tanah, dan ketersediaan aliran sungai di musim kemarau. Dalam kaitannya dengan hal tersebut, maka infiltrasi perlu diukur karena nilai kapasitas infiltrasi tanah merupakan suatu informasi yang berharga 5 bagi perancangan dan penentuan kegiatan irigasi dan pemilihan berbagai jenis komoditas yang akan ditanam di suatu lahan [7].

\subsection{Infiltrasi}

Infiltrasi merupakan proses masuknya air ke dalam tanah baik secara vertikal maupun horizontal melalui poripori tanah. Biasanya air yang terinfiltrasi ialah air hujan dan terjadi saat tanah masih dalam keadaan kering atau jenuh sebagian. Menurut Agustina dkk. (2012), penggunaan lahan yang berbeda dapat menyebabkan laju infiltrasi yang berbeda pula [8]. Tabel 1 menyajikan tentang kriteria laju infiltrasi.

Tabel 1. Klasifikasi laju infiltrasi

\begin{tabular}{lc}
\hline \multicolumn{1}{c}{ Kriteria } & Laju Infiltrasi (cm/jam) \\
\hline Sangat cepat & $>25,4$ \\
\hline Cepat & $12,7-25,4$ \\
\hline Agak cepat & $6,3-12,7$ \\
\hline Sedang & $2-6,3$ \\
\hline Agak lambat & $0,5-2$ \\
\hline Lambat & $0,1-0,5$ \\
\hline Sangat lambat & $<0,1$ \\
\hline
\end{tabular}

Kurnia dkk, (2006) menyatakan bahwa kandungan air tanah pada saat mulai terjadinya infiltrasi juga berpengaruh terhadap laju infiltrasi (Gambar 1) [9]. Oleh karena itu secara tidak langsung infiltrasi dipengaruhi oleh evapotranspirasi melalui pengaruhnya terhadap kadar air tanah awal [10].

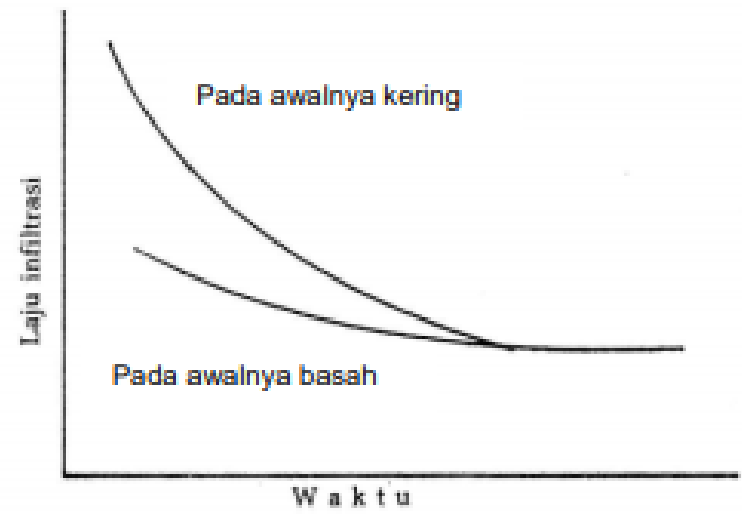

Gambar 1. Laju infiltrasi sebagai fungsi dari waktu untuk dua tanah dengan perbedaan kandungan air pada awal infiltrasi

\subsection{Faktor yang Memengaruhi Laju Infiltrasi}

Triatmodjo (2015), menyatakan bahwa laju infiltrasi dipengaruhi oleh beberapa faktor, yaitu kelembaban tanah, kedalaman genangan \& tebal lapis jenuh, topografi, penyumbatan oleh butir halus, pemadatan oleh hujan, tanaman penutup dan intensitas hujan [11-12].

\subsection{Infiltrometer}

Infiltrometer sendiri merupakan alat yang berbentuk ring atau cincin. Ada dua jenis ring infiltrometer, yaitu single ring infiltrometer dan double atau concentric ring infiltrometer. Dalam penelitian ini penulis menggunakan alat double ring infiltrometer. Penggunaan double ring infiltrometer ditujukan untuk mengurangi pengaruh rembesan lateral [13-14].

Parameter infiltrasi didapat dari nilai kapasitas infiltrasi. Kapasitas infiltrasi dihitung dari hasil pengukuran di lapangan berupa penurunan air dalam satuan luas dibagi waktu. Parameter infiltrasi metode Horton meliputi laju 
infiltrasi awal (f0), laju konstan (fc) dan konstanta untuk jenis tanah $(\mathrm{k})$. Persamaan Horton yang digunakan :

$$
f=f c+(f 0+f c) e-K t
$$

dengan:

f adalah laju infiltrasi ( $\mathrm{cm} / \mathrm{jam})$

fc adalah laju infiltrasi konstan ( $\mathrm{cm} / \mathrm{jam})$

fo adalah laju infiltrasi awal ( $\mathrm{cm} / \mathrm{jam})$

e adalah eksponensial
$\mathrm{K}$ adalah konstanta untuk jenis tanah

$\mathrm{t}$ adalah waktu

\section{Metode Penelitian}

Lokasi penelitian berada di beberapa titik di Kabupaten Sigi, Provinsi Sulawesi Tengah. Lokasi penelitian dapat dilihat pada Gambar 2. Adapun tahapan penelitian adalah seperti pada Gambar 3.

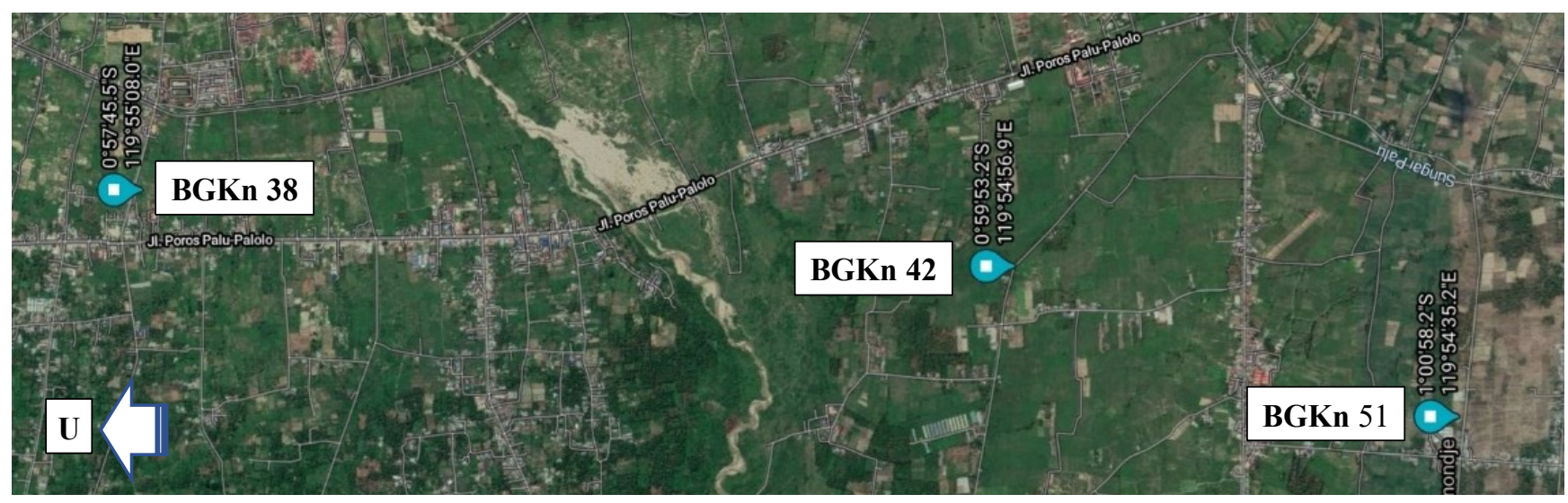

Gambar 2. Lokasi penelitian

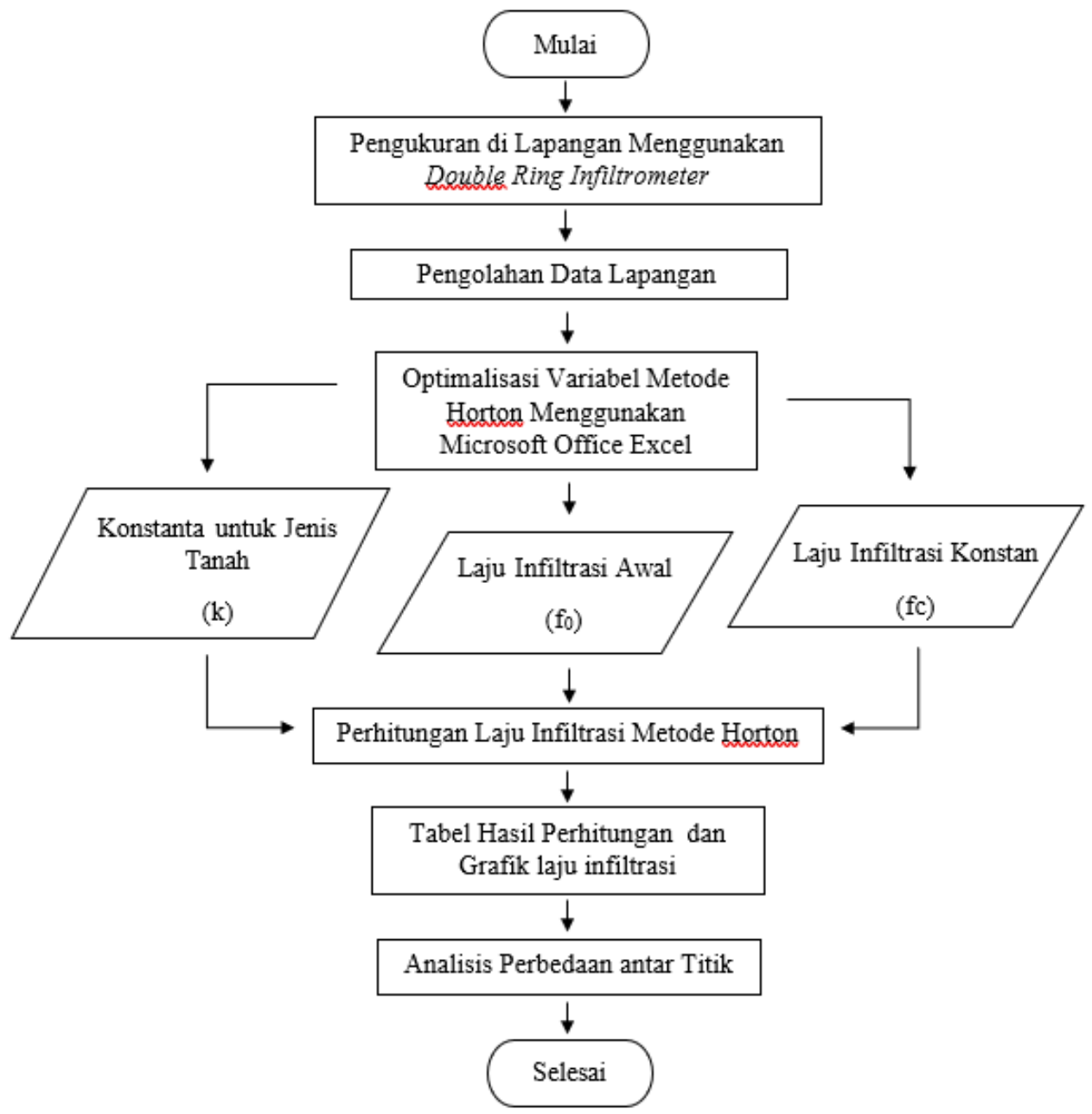

Gambar 3. Bagan alir tahapan penelitian 


\section{Hasil dan Pembahasan}

Pengukuran yang dilakukan pada lahan sawah di Kabupaten Sigi masing-masing koordinatnya yaitu (BGKn 38) $0^{\circ} 57^{\prime} 45.6^{\prime \prime S}$ dan $119^{\circ} 55^{\prime} 08.0^{\prime \prime} \mathrm{E}$; (BGKn 42) $0^{\circ} 59^{\prime} 53.2^{\prime \prime S}$ dan $119^{\circ} 54^{\prime} 57.0 " \mathrm{E}$ serta (BGKn 51) $1^{\circ} 00^{\prime} 58.2^{\prime \prime S}$ dan $119^{\circ} 54^{\prime} 35.2^{\prime \prime E}$. Masing - masing titik pengukuran tersebut memiliki elevasi yang berbeda dengan titik (BGKn 38) di 78m DPL, (BGKn 42) di 69m DPL dan (BGKn 51) di 79m DPL.

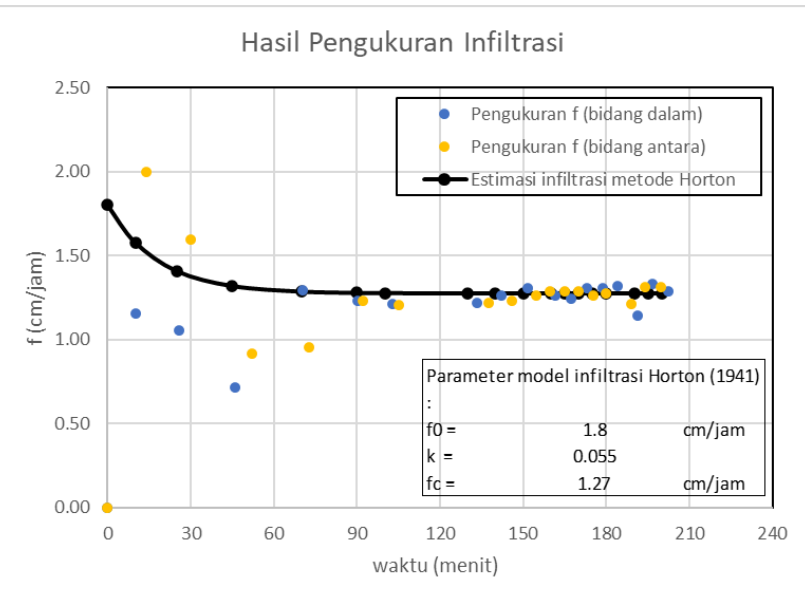

Gambar 4. Grafik hasil pengukuran infiltrasi di Titik BGKn 38

Gambar 4 menunjukkan bahwa nilai laju infiltrasi pada titik pengukuran BGKn 38, nilai f terukur mulai konstan pada menit ke 90 dengan nilai fc Horton sebesar 1,27 $\mathrm{cm} / \mathrm{jam}$. Pada titik pengukuran ini nilai f0 diambil dari persebaran data data bidang dalam dan bidang antara.

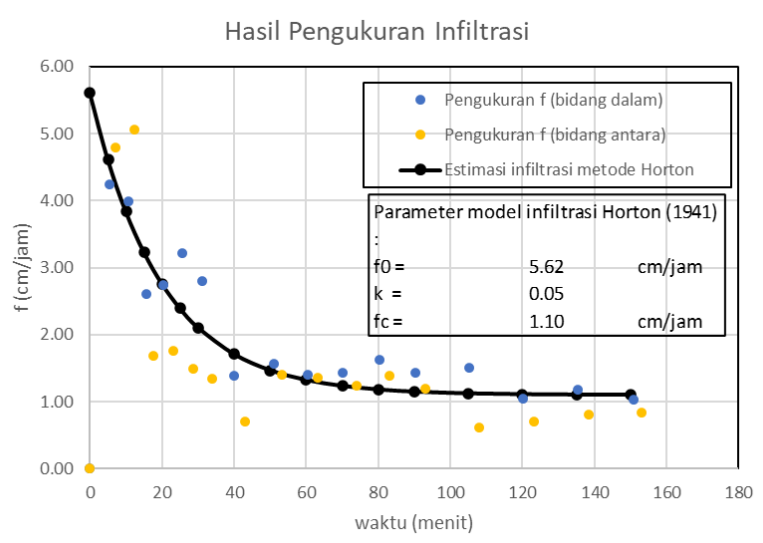

Gambar 5. Grafik hasil pengukuran infiltrasi di Titik BGKn 42

Gambar 5 menunjukkan bahwa nilai laju infiltrasi pada titik pengukuran BGKn 42, nilai f terukur mulai konstan pada menit ke 120 dengan nilai fc Horton sebesar 1,10 $\mathrm{cm} / \mathrm{jam}$. Untuk nilai f0 yang didapatkan tergolong dalam kecepatan sedang dengan kisaran 2 sampai dengan 6,3 $\mathrm{cm} / \mathrm{jam}$

Gambar 6 menunjukkan bahwa nilai laju infiltrasi pada titik pengukuran BGKn 51, nilai $\mathrm{f}_{\mathrm{t}}$ mulai konstan pada menit ke 70 dengan nilai $\mathrm{f}_{\mathrm{c}}$ Horton sebesar $0,75 \mathrm{~cm} / \mathrm{jam}$. Untuk nilai $\mathrm{f}_{0}$ yang didapatkan tergolong dalam kecepatan agak lambat dengan kisaran 0,5 sampai dengan $2 \mathrm{~cm} /$ jam.
Hasil Pengukuran Infiltrasi

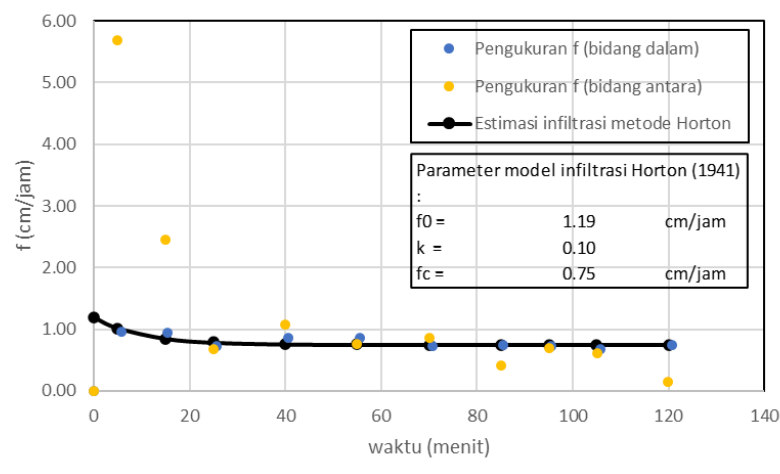

Gambar 6. Grafik hasil pengukuran infiltrasi di Titik BGKn 51

Tabel 2. Hasil perhitungan Persamaan Horton Titik BGKn 38 dan BGKn 42

\begin{tabular}{cc}
\hline \multicolumn{2}{c}{ BGKn 38 } \\
\hline $\begin{array}{c}\text { Waktu } \\
\text { (menit) }\end{array}$ & $\begin{array}{c}\text { Laju } \\
\text { Infiltrasi } \\
\text { (cm/jam) }\end{array}$ \\
\hline 0 & 1,80 \\
\hline 10 & 1,58 \\
\hline 25 & 1,41 \\
\hline 45 & 1,32 \\
\hline 70 & 1,29 \\
\hline 90 & 1,28 \\
\hline 100 & 1,28 \\
\hline 130 & 1,27 \\
\hline 140 & 1,27 \\
\hline 150 & 1,27 \\
\hline 165 & 1,27 \\
\hline 170 & 1,27 \\
\hline 175 & 1,27 \\
\hline 180 & 1,27 \\
\hline 190 & 1,27 \\
\hline 195 & 1,27 \\
\hline 200 & 1,27 \\
\hline
\end{tabular}

\begin{tabular}{cc}
\hline \multicolumn{2}{c}{ BGKn 42 } \\
\hline $\begin{array}{c}\text { Waktu } \\
\text { (menit) }\end{array}$ & $\begin{array}{c}\text { Laju } \\
\text { Infiltrasi } \\
\text { (cm/jam) }\end{array}$ \\
\hline 0 & 5,62 \\
\hline 5 & 4,62 \\
\hline 10 & 3,84 \\
\hline 15 & 3,23 \\
\hline 20 & 2,76 \\
\hline 25 & 2,39 \\
\hline 30 & 2,11 \\
\hline 40 & 1,71 \\
\hline 50 & 1,47 \\
\hline 60 & 1,32 \\
\hline 70 & 1,23 \\
\hline 80 & 1,18 \\
\hline 90 & 1,15 \\
\hline 105 & 1,12 \\
\hline 120 & 1,11 \\
\hline 135 & 1,10 \\
\hline 150 & 1,10 \\
\hline
\end{tabular}

Tabel 3. Hasil perhitungan Persamaan Horton Titik BGKn 51

\begin{tabular}{cc}
\hline \multicolumn{2}{c}{ BGKn 51 } \\
\hline Waktu (menit) & $\begin{array}{c}\text { Laju Infiltrasi } \\
\text { (cm/jam) }\end{array}$ \\
\hline 0 & 1,19 \\
\hline 5 & 1,02 \\
\hline 15 & 0,85 \\
\hline 25 & 0,79 \\
\hline 40 & 0,76 \\
\hline 55 & 0,75 \\
\hline 70 & 0,75 \\
\hline 85 & 0,75 \\
\hline 95 & 0,75 \\
\hline 105 & 0,75 \\
\hline 120 & 0,75 \\
\hline
\end{tabular}


Untuk titik ukur BGKn 38, persamaan Horton diambil dengan menggunakan data sebaran bidang antara dan bidang dalam yang dimana nilai infiltrasi bidang dalam saat rentang waktu ini lebih rendah dibanding infiltrasi konstannya. Hasil keseluruhan perhitungan laju infiltrasi dengan persamaan Horton di atas dapat di lihat di Tabel 2 dan Tabel 3.

Berdasarkan uraian perhitungan dan Tabel 2 dan Tabel 3 hasil persamaan Horton sebelumnya maka dapat dibuatkan grafik seperti Gambar 6.

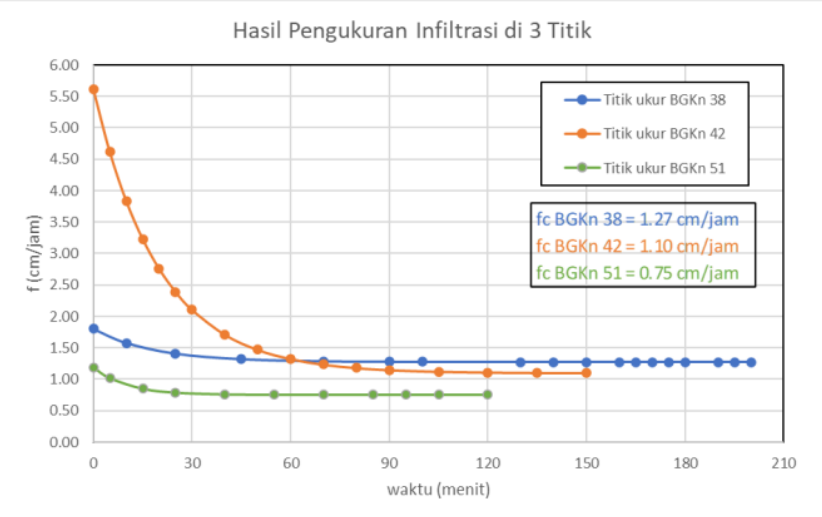

Gambar 7. Grafik hasil pengukuran infiltrasi di 3 titik

Titik pengukuran laju infiltrasi yang diambil di lapangan untuk diukur merupakan bagian yang dekat dengan bedengan sawah karena pada saat pengukuran lahan sedang ditanami tanaman jagung yang berumur kurang lebih 3 pekan. Dengan model vegetasi tersebut dan titik pengambilan yang tidak terganggu banyaknya akar tanaman tentunya laju infiltrasi masih akan tergolong lambat.

Gambar 7 menunjukkan bahwa laju infiltrasi konstan ketiga titik ukur hanya memiliki perbedaan yang relatif kecil. Nilai fc ketiga titik ukur masuk ke dalam klasifikasi agak lambat berdasarkan klasifikasi Uhland dan O'Neal dengan masing-masing fc BGKn $38=1,27 \mathrm{~cm} / \mathrm{jam}$, BGKn $42=1,10 \mathrm{~cm} / \mathrm{jam}$ dan BGKn $51=0,75 \mathrm{~cm} / \mathrm{jam}[15]$.

Untuk mengetahui kondisi tanah pada saat pengukuran hanya dilakukan dengan pengamatan secara visual pada permukaan tanah yang akan diukur. Hasil pengamatan sendiri menunjukkan bahwa kondisi tanah pada tiap lokasi titik pengukuran memiliki jenis tanah yang relatif sama dengan kelembapan/kandungan air di awal pengukuran yang berbeda. Dari Gambar 7 juga bisa diketahui bahwa kondisi tanah pada titik ukur BGKn 42 memiliki kadar air yang lebih sedikit daripada titik ukur BGKn 38 dan BGKn 51, hal ini sejalan dengan Gambar 7. Adapun hal lain yang mungkin bisa terjadi sehingga titik ukur BGKn 38 dan BGKn 51 lebih lembab dibanding BGKn 42 ialah turunnya hujan atau penyiraman yang dilakukan oleh petani setempat sebelum pengukuraan dilakukan di lokasi tersebut.

Perbedaan yang bisa dilihat dari ketiga titik pengukuran ditunjukkan pada laju awal infiltrasi dengan titik ukur BGKn 42 lebih cepat dibanding dengan titik ukur BGKn 38 dan BGKn 51. Namun demikian, untuk gambaran laju infiltrasi yang ideal hanya ditunjukkan oleh titik ukur BGKn 42 dengan laju infiltrasi awal yang nilainya berbeda jauh dengan laju infiltrasi konstannya. Untuk titik ukur BGKn 38 di sini kita dapat melihat pengaruh dari kecilnya ukuran cincin ukur yang digunakan. Di mana laju infiltrasi awal bidang dalam lebih rendah dibanding laju infiltrasi konstannya. Sedangkan pada titik Ukur BGKn 51 kita bisa lihat bahwa persebaran datanya memang tidak seburuk titik ukur BGKn 38 akan tetapi dengan laju infiltrasi awal yang tidak jauh berbeda dengan laju infiltrasi konstannya tentunya hal ini menunjukkan bahwa kondisi tanah yang diukur kurang ideal untuk dijadikan sampel.

\section{Kesimpulan}

Beberapa kesimpulan yang diperoleh dari hasil penelitian ini adalah:

1). Nilai $f_{c}$ dari ketiga titik ukur BGKn 38 , BGKn 42 dan BGKn 51 berdasarkan klasifikasi Uhland dan O'Neal, masih tergolong "agak lambat" dengan masing-masing nilai $\mathrm{f}_{\mathrm{c}}$ yaitu $1,27 \mathrm{~cm} / \mathrm{jam}, 1,10 \mathrm{~cm} / \mathrm{jam}$ dan $0,75 \mathrm{~cm} / \mathrm{jam}$.

2). Untuk nilai perbedaan $\mathrm{f}_{\mathrm{c}}$ nya, BGKn 38 dengan $\mathrm{BGKn}$ 42 senilai $0,17 \mathrm{~cm} / \mathrm{jam}$ dan BGKn 42 dengan BGKn 51 senilai 0,35 cm/jam, sehingga BGKn 38 dengan BGKn 51 senilai $0,52 \mathrm{~cm} / \mathrm{jam}$. Sedangkan untuk nilai perbedaan $\mathrm{f}_{0}$ dari ketiga titik yaitu $\mathrm{BGKn} 38$ dengan BGKn 42 senilai 3,82 cm/jam dan BGKn 42 dengan BGKn 51 senilai $4,43 \mathrm{~cm} / \mathrm{jam}$, serta BGKn 38 dengan BGKn 51 senilai $0,61 \mathrm{~cm} / \mathrm{jam}$.

\section{Daftar Pustaka}

[1] R.L. Jauda, O.E.H. Laoh, J. Baroleh, J.F.J. Timban, "Analisis Pendapatan Usahatani Kakao di Desa Tikong”, Agri-Sosioekonomi, vol. 12, no. 2, p. 33, 2016.

[2] R. Fauzi, F. Yussriah, D. Hadian, and D. Sapari, "Liquefaction Susceptibility Zonation Based on Correlation of Water". Proc. Peran Penelitian Ilmu Kebumian Dalam Pembangunan Infrastruktur di Indonesia, vol. 2017, p. 1, 2017.

[3] A. Tohari, K. Sugianti, and E. Soebowo, "Liquefaction Potential at Padang City: A Comparison of Predicted and Observed Liquefactions", Riset Geologi dan Pertambangan, vol. 21, no. 1, p. 7, 2011.

[4] S. Kurniawan, Karakteristik Tanah Terdampak Dan Tidak Terdampak Likuifaksi Berdasarkan Uji Swedish Weight Sounding Pada Kelurahan Petobo, Palu: Jurusan Teknik Sipil Univ. Tadulako, 2020.

[5] C. Asdak, Hidrologi dan Pengelolaan Daerah Aliran Sungai, Yogyakarta: Gadjah Mada University Press, 2002.

[6] E. Yimer, I. Messing, S. Ledin, and A. Abdelkadir, "Effects of Different Land Use Types on Infiltration Capacity in A Cathoment in the Highlands of Ethiopia", Soil Use and Management, vol. 24, p. 344, 2008.

[7] I. Purwanto and Ngaloken, "Pengaruh Berbagai Jenis Vegetasi Terhadap Kapasitas Infiltrasi Tanah di Cijambu, Sumedang, Jawa Barat", Buletin Penelitian Hutan, vol. 573, p. 13, 1995.

[8] D. Agustina, D.L. Setyowati, and Sugiyanto, “Analisis Kapasitas Infiltrasi Pada Beberapa Penggunaan Lahan 
di Kelurahan Sekaran Kecamatan Gunungpati Kota Semarang”, Jurnal Geo Image, vol. 1, no. 1, p. 92, 2012.

[9] U. Kurnia, F. Agus, A. Adimihardja, and A. Dariah, Sifat Fisik Tanah dan Metode Analisisnya, Jakarta: Balai Besar Litbang Sumberdaya Lahan Pertanian, 2006.

[10] M.L. Sharma, G.A. Gander, and C.G. Hunt, "Spatial Variability of Infiltration in Watershed", Journal of Hydrology, 45, p. 101, 1980.

[11] B. Triatmodjo, Hidrologi Terapan, Yogyakarta: Beta Offset, 2015.

[12] S. Arsyad, Pengawetan Tanah dan Air, Bogor: Departemen Ilmu-Ilmu Tanah Fakultas Pertanian Institut Pertanian Bogor, 2000.
[13] A.R. Darajat, F. Nurrochmad, and R. Jayadi, “Analisis Infiltrasi Di Saluran Primer Daerah Irigasi Boro Kabupaten Purworejo, Propinsi Jawa Tengah", RENOVASI : Rekayasa Dan Inovasi Teknik Sipil, vol. 4, no. 1, p. 1, 2019.

[14] A. Anggrianti, A. Anugrahadi, and H.F. Yuda, "Analisis Laju Infiltrasi Daerah Ternate Barat Serta Ternate Utara Provinsi Maluku Utara", Journal Geoscience Engineering and Energy (JOGEE), vol. 2, no. 1, p. $88,2021$.

[15] R. Uhland and A. O'Neal, Soil permeability determination for use in soil and water conservation. SCS-TP-101. Washington: United States Department of Agriculture, 1951. 